\title{
Cash Transfer and the Economic Well-Being of Persons with Severe Disability in Wajir County, Kenya
}

\author{
Issa Kurash Abdille², Dr. Patrick Mbataru² \\ ${ }^{1}$ Correspondent Author, Master of Arts in Public Policy and Administration Student, \\ Kenyatta University, Kenya \\ ${ }^{2}$ Department of Public Policy and Administration, Kenyatta University, Master Of Arts In \\ Public Policy And Administration, Kenyatta University
}

\section{ABSTRACT}

Social interventions such as cash transfers provide the much needed support to vulnerable people. People living with disabilities continue to remain economically deprived, experiencing high levels of poverty. In Wajir County, this crisis is more exacerbated by the nomadic setting where disabled persons are left behind as other individuals move. They are left to cater for themselves due to their mobility constraints. The welfare of these people continue to deteriorate since they are unable to work and highly depend on others and hence do not have the capacity of self-sufficiency. These people remain dependent on the government and non-governmental agencies. The effect of cash transfer programs however, is not fully known. This study sought to assess the effect of cash transfer on the economic well-being of people with severe disabilities in Wajir County. The study is founded on the Maslow's theory of needs, the sustainable livelihoods framework and the rights-based approach. The study employed mixed methods research design and targeted all family heads for all the 183 under the Persons with Severe Disabilities Cash Transfer in Wajir North and Tarbaj sub-Counties as at 2015 and 19 senior officials working with the sub-counties' social development offices. The study used primary data obtained through semi-structured questionnaires and interview guides. Data analysis methods that be employed involved quantitative and qualitative approaches. The qualitative data was analysed using content analysis where the information obtained was reported in a narrative form and direct quotes. Quantitative data was analyzed using descriptive statistical methods. Quantitative data analysis was facilitated by the Statistical Package for Social Sciences Version 20. Descriptive statistics such as the rate of response, frequency distribution, mean and standard deviation were used. Inferential statistics generated included correlation and regression analysis. The study findings showed that cash transfer supported household income, healthcare access, investment in productive activities and empowerment had positive and significant effect on the economic wellbeing of persons living with disabilities in Wajir County. The study concluded that if the cash transfer programme was to achieve its objectives and transform the economic wellbeing of the beneficiary households, the aforementioned support areas needed to be adequately embedded in the programme's plan. The study made several recommendations among them that the Ministry of Labour, Social Security and Services Programmes should consider increasing the monthly disbursements given to persons living with disabilities so that they can venture in to activities that would give them supplementary incomes. There can be other activities within the programme meant to support the beneficiaries to be self-reliant so that they do not have to rely on the transfers throughout. The study also recommends that the officials overseeing the cash transfer programme for persons living with disabilities should have follow up programs especially for beneficiaries who have ventured in to productive activities so that they can support them to expand their income generation activities. The programme can partner with other development partners such as donors and NGOs and also the county government to create a fund where beneficiaries can get more assistance both financial and non-financial in order to expand 
their activities. The study further recommends that the programme should provide networking programs were beneficiary households can interact with various organizations so as to secure livelihood opportunities such as employment among others.

Keywords: Cash Transfer, Economic Well-Being, of Persons Disability, Severe Disability, Wajir County

DOI 10.7176/ijcab.v3iIII.36, URN: urn:nbn:de:0000ijcab.v3iIII.367

\section{Cite this Article:}

Abdille, I., \& Mbataru, P. (2019). Cash Transfer and the Economic Well-Being of Persons with Severe Disability in Wajir County, Kenya. International Journal of Current Aspects, 3(III), 135-153. http://journals.ijcab.org/journals/index.php/ijcab/article/view/36

\section{INTRODUCTION}

Chronic poverty, hunger and HIV/AIDS are triple threats that are being eradicated by social transfers. There is a need to set up programs that would protect human rights and the under privileged in the society. These programs would ensure that they are financially secure, have enough food and solve fuel crisis. The programs too would cater health services to eradicate infectious and non-communicable diseases (Banerji \& Gentilini, 2013). A powerful way that helps fight poverty and promote inclusive growth among vulnerable population globally all over the world is through Social Protection (SP). In Africa, the African Union Social Policy Framework has highlighted SP as a key strategy to reduce poverty (Andrews, Das, Elder et $a l ., 2012)$. Cash transfer and public works are the most popular SP interventions. There are many other interventions like reforms to pension schemes (Onyango-Ouma \& Samuels, 2012). Cash transfer is the money that is given to vulnerable people as a gesture of assistance. This helps eradicate hunger, acute poverty, emotional and physical breakdown as an SP remedy (Ressler, 2008). Cash transfers are provided by the government and nongovernmental organizations (NGOs) to individuals or families. They are regular and noncontributory payments of money. The objective of cash transfers is to reduce long-term or shock-induced poverty that addresses social risk and economic vulnerability (Giovannetti, 2010).

Cash transfer is a social contract with citizens that includes; disability grants, social pensions, child support grants, orphan care grants and transfer to poor households among others (Samson et al., 2011). Cash transfers can be conditional or unconditional. Conditional cash transfers are aimed at improving school attendance, regular health check-ups and nutrition. These schemes are now viewed as a right of citizenship and is now evident that it has helped eradicate hunger, improve living standards, education and health of families that need help (Adato \& Bassett, 2008). Cash transfers have indeed been helpful to many countries in Africa and beyond. These countries include; South Africa, Nicaragua, Colombia, Brazil, Honduras, and Mexico (Bryant, 2009). In Kenya, the first step that was taken to improve Social Security and Protection (for those suffering from high risk of poverty and seclusion from the general population) led to the initiative of National Safety Net Program (NSNP). Its main objective is to empower operational system and improve the five cash transfer initiatives which are: Older Persons Cash Transfer (OPCT), Cash Transfer for Orphans and Vulnerable Children (CTOVC), Hunger Safety Net Program (HSNP), Urban Food Subsidy Cash Transfer (UFS-CT), and Persons with Severe Disability Cash Transfer (PWSD-CT). The program has involved and brought in development partners in Kenya. An estimate of Kenyan population as at 2010 was 38,610,097 (KNBS, 2010). People with disability was estimated to be 10\%. Persons with Severe Disability Cash Transfer (PWSD-CT) was initiated to advance the capability of 
livelihoods (Mutiga \& Wanyoike, 2016). Cash transfers that target people with disability are among the least known programs (Mitra, 2010). Countries with low income rates have low take rates for the people with disability in the program for example India (World Bank 2007; p.113). In countries like Brazil, Namibia and South Africa, the size of these programs have increased though not many people appreciate the impact they make in some people's lives. A non-contributory and means-tested Disability Grant (DG) is found in South Africa. This program is set to help the physically or mentally challenged who are mature enough to work but cannot (Oddsdottir, 2014). In Kenya, resources for such programs are scarce. This makes many people who need and deserve such assistance to be left without any help. In some areas, about four out of eight Persons with Severe Disability (PWSD) benefit from the program. Safety Net covers only $0.38 \%$ of this group of people (Agboga, 2015).

Swords, Merriman, and O'Donnell (2013) view the well-being of human beings as activities that signify a state of life condition one has attained and experienced; a concept that refers to any assessment in evaluating a person's life situation or 'being', hence, a description of individuals' life situation (McGillivray, 2007) and many social scientists highlight the need for the inherent nature of a persons, human well-being, happiness, life satisfaction or subjective well-being (Tiliouine, 2007). These terms are often used interchangeably. Earning capability and economic resource are often not seen as an end but rather as a way off which an individual is able to obtain support for a specific standard of living. Variables which can help measure the economic well-being include: income, wealth, spending on consumer goods, housing conditions and ownership of durable goods (Schwarze, 2008). People living with disabilities are the most vulnerable group of people. Over a billion of people in the world, an estimate by the United Nations, have some form of disability and are not well represented in the society. Poor people are at high risks of suffering from catastrophic health expenses, disaster, violence and many other hardships. People with disability have many challenges because of their attitudinal, physical and financial limitation (Hawking, 2014)". Disabled people depend on other people because they cannot work. Therefore, they lack the power of self-sufficiency. People who suffer from prolonged physical well-being and the inability to do basic routines often face stigmatization that results to subsequent decline in social capital (Lerisse, et al., 2013).

People who have any kind of disability appear to be financially helpless due to reduced earning capacity associated with functional limitations. Accommodating certain limitations that have high susceptibility often lead to substantial costs and financial shocks (LaPlante, 2013). Many disabled people are either near or are at the poverty level (Kaye, 2011). Many who suffer from mental illness or 'abnormal diseases' are homeless. The number of people with disability living in a subsistent level and maintain some level of independence is seen as a major result of an adverse event. Other reasons that contribute to the fact that people with disability are poor is that, this group of people are not educated and no labour market (Buddelmeyer \& Verick, 2008; Parodi \& Sciulli, 2008; Mitra, Findley, \& Sambamoorthi, 2009; She \& Livermore, 2009; Houtenville, 2009). An OECD study done in 2009 that covered 21 upper-middle and high-income countries showed that poverty levels were high among people living with disabilities compared to well-abled people. Only three countries had the opposite result which are Norway, Slovakia and Sweden. World Health Organization (WHO) released an analysis of a survey which showed that, in fifteen developing countries, people living with disabilities spent more on health care than any other household requirement (for 51 World Health Surveyed countries). For instance, a study done in Sierra Leone showed that people with severe disability spent an average of 1.3 times on health care than the well-abled people (Trani, Bah, Bailey et al., 2010). Surveys conducted in Malawi and Namibia show that income and household consumption are very low (Eide \& Loeb, 
2005). However, in South Africa, research suggested that the income of households with people with disabilities are high. This is because, these household receive disability grants. Eastern Cape Province leads in giving out disability grants (Loeb et al., 2008).

Low income rates eventually mean that there is no investment made. A study shows that people living disabilities have fewer assets and the living standards are poor compared to the households that do not have people living with disabilities (Eide \& Kamaleri, 2009; O'Keefe, 2009; Trani et al., 2010). A survey to estimate the extra costs in households with people living with disabilities was done. In the United Kingdom, it ranged from 11\%-69\% (Zaidi \& Burchardt, 2005). The range for Australia was 29\%-37\% (Saunders, 2006). Ireland ranged from 20\%-37\% (Cullinan, Gannon\& Lyons, 2011). The range for Vietnam was 9\%-14\%. In Bosnia and Herzegovina, it ranged at 14\% (Braithwaite \& Mont, 2009). The data showed that the households with people living with disabilities were high. In Kenya, people living with disabilities and other countries are economically deprived. The barriers that are responsible for these are; stigma, marginalization, low self-esteem, poverty, limited access to various opportunities and benefits (Mutiga \& Wanyoike, 2016). The most vulnerable people living with disabilities are children, women and youth. Other factors include gender, social status and age. These group of people face challenges such as labour market which prohibits free access to opportunities and information. Kenya has however tried to change and improve its economic empowerment and perception over the last 10 years. The government has also improved on the disability grants and cash transfer that these group of people need.

The cash transfers have a huge impact not only to the recipient but also the particular household, wider community and eventually the country. This means that cash transfers have a huge impact in a society and also reduces dependency. This means an economical growth in the country (Moller \& Fereira, 2003; Vincent \& Cull, 2009). More benefits are experienced such as access to basic health care, formation of social support networks, food security, school fees, boost in self-esteem and dignity among others. This is according to Abdulla (2015). Cash transfer programmes, function primarily as a safety net in countries such as Kenya, Ghana and Zimbabwe which has led to an increase in investment on household economic activities, in cases with households particularly headed by females (Asfaw, Daidone, Davis et al., 2012). Davis and Handa (2014) noted that cash transfer gave the beneficiaries hope to want to invest in the future. Samson (2004) asserted that, cash transfer had an important direct impact in terms of promoting nutrition. Cash transfers increased the purchasing powers of families which received the benefits (Kimosop, 2013). Cash transfer programme are seen to provide steady and reliable source of income. This had a significant effect upon the capacity of households to invest in the future and overcome the threat of a long term, persistent poverty (Barrientos \& Lloyd-Sherlock, 2002). Cash transfers have reduced household vulnerability through asset accumulation and more stable income flows that allow them to have a better plan for their expenses, pay their debts and get credits more easily, resulting in increasing consumption of goods and service (Latapí, 2005). Improved nutritional status directly promotes improved health status of household members and cash transferred to households allowed recipients to afford good treatment on time thereby improving their productivity (Handina, Ncube, Jordaan et al., 2010). Vincent, Cull (2009) concluded that cash transfers promoted self-esteem, status and empowerment among the under privileged, enabling them to be active members of their households and communities, rather than burdens

Wajir County, located in the North-Eastern region of Kenya covering a wide geographical area of $56,685.9 \mathrm{Km}^{2}$. It has a higher poverty rate of $84 \%$, making it the $3^{\text {rd }}$ poorest county in Kenya, with the majority of the population unable to meet basic household needs. The County has an experience with cash transfer program from the government and non- 
governmental organizations where more than 25,879 households depend on these cash transfer (Abdulla, 2015). As at 2015, 550 households were covered under the Persons with Severe Disabilities Cash Transfer. The Kenya Development Response to Displacement Impacts Project 2017 highlights that, the pastoral nature of the communities in Wajir County with persons with disability tends to be left behind as household move and have low level of education and skills for effective engagement in income generating activities. In addition, given the nomadic setting, there may be more people living with disability than in other populations. Disabled members cite exclusion as their limited mobility prevents their participation in traditional life (nomadic lifestyle) and families consider them bad omens (Northern Nomadic Disabled Persons' Organisation, 2013).

\section{STATEMENT OF THE PROBLEM}

This study aims to assess impact of cash transfer on the economic well-being of people with disabilities in Wajir County. Despite the level of economic growth and modest increases in incomes within the Kenyan economy, vulnerable groups more particularly people living with disabilities continue to remain economically deprived, experiencing high levels of poverty (World Bank, 2016). In Wajir County, this crisis was more exacerbated by the nomadic setting where people living with disabilities were left behind as other individuals moved due to their mobility constraints, left to cater for themselves. The welfare of these persons therefore continued to deteriorate since they were unable to work for earnings and were highly dependent on the work of others and hence did not have the capacity to selfsufficiency. Therefore, these people remained highly dependent on the assistance from the government and other NGO's. Even though studies had been conducted to show effects of cash transfers on vulnerable households, the concentration, particularly in Kenya had been on cash transfers for the orphans and the elderly people. For instance, the studies by Asfaw et al (2012), Ayuku et al. (2013), Handa (2012), Mogaka (2013) focused on the effects of cash transfers for the orphans and vulnerable children while the studies by Mwanzia (2012) and Kimosop (2013) focused on the cash transfers for the elderly. Even though a study conducted by Mutiga and Wanyoike (2016) focused on cash transfers for the people with severe disabilities in Rongai Sub-county, the study had a different objective from this study and focused more on the design of the programme such as beneficiary targeting. Similarly, the study by Bernabe-Ortiz et al. (2016) though focused on people with disabilities, the objectives of the study differed from those of the current study and the context was in Peru. The review of the literature also showed that a large number of the studies on cash transfers only gave a general effect of these transfers and did not show the manner in which the beneficiaries' livelihoods had been transformed. For instance, the study by Stefanoni et al. (2017) acknowledged that cash transfers enabled the elderly to access better healthcare but did not show how such affected their livelihoods. Aluoch (2013) also noted that cash transfers for the OVC enabled households to own product assets but did not show how these productive assets helped improve the wellbeing of the households. This study therefore sought to fill the mentioned gaps by assessing the effects of cash transfer on the economic wellbeing of people with severe disabilities in Wajir County.

\section{OBJECTIVES OF THE STUDY}

The main aim of this study was to assess the effect of cash transfer on economic well-being of persons with severe disabilities in Wajir County, Kenya.

The specific objectives of the study were;

i. To determine the effect of cash transfer supported household income on the economic well-being of persons with severe disabilities in Wajir County. 
ii. To find out the effect of cash transfer supported healthcare access on the economic well-being of persons with severe disabilities in Wajir County.

iii. To examine the effect of cash transfer supported investment in productive activities on the economic well-being of persons with severe disabilities in Wajir County.

iv. To establish the effect of cash transfer supported empowerment on the economic wellbeing of persons with severe disabilities in Wajir County.

\section{THEORETICAL FRAMEWORK}

\subsection{Maslow's Theory of Needs}

This was developed by Abraham Maslow in 1968. The theory proposes a hierarchy of human needs that is applicable to the human services model (Judge \& Vampbell, 2010). The Hierarchy consists of 5 levels. (1) Physiological needs. These are the literal requirements for human survival. These include: Food, shelter, oxygen. (2) Safety needs. This safety could be economic or physical. Economic needs manifest itself in form of: job security, insurance policies. Safety needs include: personal needs, financial needs, health and wellbeing, safety net against accidents among others. (3) Love and belonging. This is a social need related to intimacy and acceptance from others. (4) Esteem needs: Esteem presents the normal human desire to be accepted and be valued by others. It implies recognition by others that a person is competent or respected. (5) Self-actualization: These needs relate to the fulfilment of a person's innate potential as a human being. Self-actualized people possess attributes that are consistent with highly competent and successful individuals (Orando, 2013).

Maslow's hierarchy of needs is often portrayed in the shape of a pyramid, with the largest and most fundamental levels of needs at the bottom (physiological needs), and the need for selfactualization at the top (Miako \& Wanjohi, 2017). Cash transfer enables households with persons with severe disabilities to meet their fundamental needs (physiological needs) of food, shelter and clothing (Kimosop, 2013). Physiological needs bring fulfilment in the person hence making it possible for persons to achieve the other needs in the pyramid which include: esteem, need to love and be loved, safety needs and finally self-actualization (Schuck \&Rosenbaum, 2006). Provision of cash transfers reactivates households with persons living with severe disabilities to engage for instance, in productive activities such as farming which may generate further incomes and also to be empowered economically and socially through support groups and merry go rounds and the like. It makes it possible for them to contribute to meeting household needs of food, shelter, clothing among others (Mutambara, 2014). This hierarchy of needs was useful in illustrating the needs of households with persons living with severe disabilities and the role of cash transfer programme in supporting these households to meet these needs in order to reach their potentials.

\subsection{The Sustainable Livelihoods Framework and the Rights-Based Approach}

The study is anchored on the sustainable livelihoods approach associated with Robert Chambers and Gordon Conway (1991) and the rights-based approach. Rights-based and sustainable livelihoods approaches are complementary perspectives popularized by DFID in the 1990s. The approaches seek to achieve the same goal: empowerment of the most vulnerable and a strengthened capacity of the poor to achieve secure livelihoods. The rightsbased perspective establishes a link between public institutions and civil society, particularly how to increase the accountability of public institutions to the socially disabled citizens. The livelihoods approach takes as it starting point a need to understand the livelihoods of poor people in context. From this starting point, it tries to identify the specific constraints which prevent the realization of people's rights and consequently the improvement of their livelihoods on a sustainable basis (Nkpoyen, Mbat, \& Eteng, 2015). 
Livelihood is the ways and means by which people make and sustain a living (Daniels, 1999). By and large, the concept not only encompasses processes and practices beyond income generating activities, but also the institutional, social and organizational environment that people operate in. Owen (2011) asserts that it is necessary for humans to participate in the labour market not only for sustenance and survival but also to contribute to their self-esteem and fulfilment. The Sustainable Livelihoods Framework (SLF) is grounded on the work of Robert Chambers in the 1980's.

Chambers and Conway (1992) assert that a livelihood within this framework encompasses assets, capabilities and activities required to support a means of living. A sustainable livelihood is one which can cope with and recover from stress and shocks that come its way. It can enhance its capabilities and assets and present sustainable opportunities both now and in the future. The approach conceptualizes sustainability in a multi-faceted fashion where capital is natural, human, physical, personal, social, and financial, and exists in a vulnerability context of stresses, shocks, and trends. The SLF depicts stakeholders as operating in a vulnerability context within which they acquire value and meaning for their assets based on prevailing institutional, social and organizational environment. The vulnerability context therefore plays a major role in determining livelihood strategies that are open for people to pursue beneficial livelihood outcomes (Ahmed et al., 2011). Devereux (2001) explains that the vulnerability context comprises trends such as demographic trends, governance and resource trends; seasonality i.e. of products, prices or employment opportunities and shocks e.g. natural hazards like floods and earth quakes. This context forms part of the framework that is furthest beyond the stakeholder's control

The approach is people-cantered; it is interested in how a person's livelihood changes over time and the vulnerabilities they encounter. The SLF is holistic in that it acknowledges many strategies are employed in securing livelihoods and these are influenced by exogenous factors such as government policies and institutional dynamics and processes (PIP). It builds on strengths rather than weaknesses, encourages public-private partnerships, and seeks to understand the nature of livelihoods and their influencing factors. It emphasizes sustainability as important if development is to be lasting (Morse \& McNamara, 2013). The Sustainable Livelihoods model had been adopted because unlike most traditional models such as the human rights-based approach, it tackled poverty based on multiple factors like economic, social, political, ecological as well as an individual's ability to sustain a livelihood (Krantz, 2011). The cash transfer programme beneficiaries were a vulnerable group that encountered stresses (disability, limited entrepreneurial skills, negative public attitudes), shocks (equipment breakdown, power disconnection) and were threatened by unfavourable trends (market prices, government policy) in their quest for a livelihood through the small enterprises (Norton \& Foster, 2011). Their economic empowerment was dependent on the healthy interaction between the various forms of capital and stresses, shocks, trends, policies, institutions and processes within which their enterprises operate (Majale, 2012).

\section{CONCEPTUAL FRAMEWORK}

In this research, a conceptual framework had been developed to show the impact of cash transfer programmes on economic well-being of vulnerable households in Wajir County, Kenya. 


\section{Independent Variables}

Cash Transfer Supported Household Income

- Monthly income from activities started using cash transfer money

- Average monthly household expenditures since enrolment in the CT programme

- Main source of income for the household

\section{Cash Transfer Supported Health Access}

- Usage or number of visits to health facilities since enrolment in the CT programme

- Amount of health expenses since enrolment in the CT programme

- Number of household members with other health problems since enrolment in the CT programme

\section{Cash Transfer Supported Investment in} Productive activities

- Access, amount and value of productive assets owned (livestock, agricultural, land, human capital etc.) since enrolment in the CT programme

- Involvement in small businesses since enrolment in the CT programme

- Amount of household savings and borrowing since enrolment in the CT

\section{Cash Transfer Supported Empowerment}

- Number of empowerment programmes the household is attached to since enrolment in the CT programme

- Membership to support groups/chamas since enrolment in the CT programme

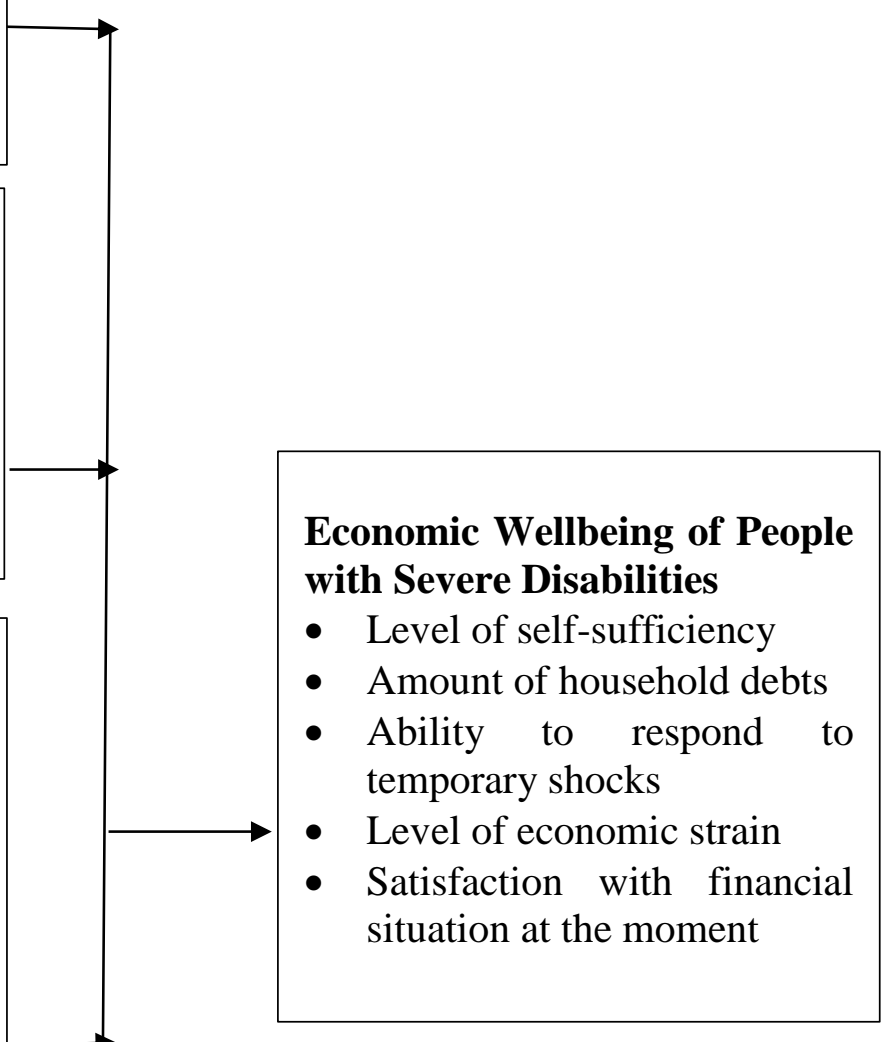

\section{Figure 1: Conceptual Framework}

\section{RESEARCH METHODOLOGY}

This study applied a mixed methods research design where both qualitative and quantitative methods was applied. This design was chosen since the researcher used both qualitative and quantitative data and by so doing, the researcher was equipped with different kinds of information, detailed views of participants qualitatively and scores on instruments quantitatively and together they yielded results that should be the same allowing them to carry out a comprehensive study of the research issue in line with Creswell (2014). According to Jagongo (2009), no single design exists in isolation and combining different designs in one study increases validity of the findings. Wajir County has an estimated area of $56,685.9 \mathrm{Sq}$. Km of which 30 per cent is arable. It shares its board with the Republic of Somalia to the East, on the south Garissa County, on the Southwest Isiolo, on the West 
Marsabit County, on the Northwest Moyale County, on the North the Republic of Ethiopia and on the Northeast Mandera County. Wajir town is the major economic hub and is about $720 \mathrm{~km}$ from the Capital city of Kenya, Nairobi. The population predominantly depends on livestock rearing as the main source of livelihood and practice pastoral nomadism (GoK, 2002). The County consists of four livelihood zones: North, primarily agro-pastoral; East and South, primarily pastoralism and some agro-pastoral; West, mainly pastoralism. In Wajir East, there is also an active gum Arabic trade (GoK, 2002). The study areas were selected because of their fair representation of both agro-pastoralism and pastoralism livelihood zones in the county. The study targeted 183 Households in Wajir County with persons living with severe disabilities focusing on Wajir North and Tarbaj sub counties as at 2015 (Ministry of Labour, Social Security and Services Programmes, 2015). The study also targeted 19 senior officials working with the sub-counties' social development offices. Source: Ministry of Labour, Social Security and Services Programmes (2015), Wajir North and Tarbaj SubCounties' Social Development Offices (2017)

The study used semi-structured questionnaires and interviews as data collection method. The questionnaires were given to the household heads while the interview guide was used for the key informants who were the sub-county social development offices senior officials. The questionnaires were useful in collecting objective data about the experiences of the households benefitting from the cash transfers and they were less costly consuming less time. The questionnaire was divided into the five sections as per the study objectives. All these five sections were preceded by a section dealing with demographic information of respondents. The use of in-depth interviews was resourceful in providing relevant and rich information/data about the research study. The interviews allowed the researcher to obtain detailed information of how persons living with disabilities had been affected by the cash transfer programme. The methods used in analysing the data involved quantitative and qualitative procedures. The qualitative data from the interviews was analysed using content analysis where the information obtained was reported in a narrative form based on the theme of the study. Quantitative data was analysed using descriptive statistical methods. The steps followed included editing, coding, and data entry. Quantitative data analysis was facilitated by SPSS (Statistical Package for Social Sciences) Version 20. Microsoft excel was used to complement SPSS especially in production of diagrams and tables. Descriptive statistics such as a rate of response, the frequency distribution, the mean and standard deviation were used. Inferential statistics that were generated included correlation and regression analysis. Pearson's correlation analysis was used to establish the association between the dependent and the independent variables. A multiple linear regression model was used to quantify the effect of cash transfer on economic well-being of people with severe disabilities in Wajir County, Kenya. The choice and justification of using multiple linear regression model was that it was useful in testing the causal/effect relationship between cash transfer supported household income, healthcare access, investment in productive activities and empowerment within beneficiary households and their economic wellbeing. The equation below shows the multiple linear regression model of the independent variables against the dependent variable.

\section{STUDY FINDINGS}

The direction, strength and significance of the associations between the independent variables with the dependent variable were investigated. Pearson correlation coefficient was used in this study and it ranges from -1 to +1 . The interpretation of the strength of coefficients as given by Sedgwick (2012) is as follows: .00 to .19 is very weak, .20 to .39 is weak, .40 to .59 is moderate, 60 to .79 is strong while .80 to 1.0 is very strong. In this study, the significance of the association between the variables was tested at $95 \%$ confidence level or the 0.05 significance level. The rule of the thumb was that a calculated $\mathrm{p}$ value greater than the critical 
$\mathrm{p}$ value which was set at 0.05 for this study implied that the correlation between the variables was insignificant and vice versa.

The findings as presented in Table 1 reveal that cash transfer supported household income had a strong positive and significant correlation with the economic well-being of persons with severe disability in Wajir County given $(r=0.755, p=0.000, p<0.05)$. The findings also showed that cash transfer supported healthcare access and the economic well-being of persons with severe disability in Wajir County were positively and significantly associated and their association was strong $(\mathrm{r}=0.679, \mathrm{p}=0.000, \mathrm{p}<0.05)$. The study further found that cash transfer supported investment in productive activities had a strong positive and significant association with the economic well-being of persons with severe disability in Wajir County as shown by $(r=0.726, p=0.000, p<0.05)$. The correlation between cash transfer supported empowerment and the economic well-being of persons with severe disability in Wajir County was also found to be positive and significant and this association was strong $(\mathrm{r}=0.699, \mathrm{p}=0.000, \mathrm{p}<0.05)$. These findings implied that cash transfer was positively and significantly correlated with the economic well-being of persons with severe disability in Wajir County.

Table 1: Correlation Matrix

\begin{tabular}{|c|c|c|c|c|c|c|}
\hline & & $\begin{array}{l}\text { Economic } \\
\text { Wellbeing }\end{array}$ & $\begin{array}{c}\text { CT } \\
\text { Supported } \\
\text { Household } \\
\text { Income } \\
\end{array}$ & $\begin{array}{c}\text { CT } \\
\text { Supported } \\
\text { Healthcare } \\
\text { Access }\end{array}$ & $\begin{array}{c}\text { CT } \\
\text { Supported } \\
\text { Investment } \\
\text { in } \\
\text { Productive } \\
\text { activities }\end{array}$ & $\begin{array}{l}\text { CT Supported } \\
\text { Empowerment }\end{array}$ \\
\hline & $\begin{array}{l}\text { Pearson } \\
\text { Correlation }\end{array}$ & 1 & & & & \\
\hline Economic & Sig. (2-tailed) & & & & & \\
\hline Wellbeing & $\begin{array}{l}\mathrm{N} \\
\text { Pearson } \\
\text { Correlation }\end{array}$ & $\begin{array}{c}93 \\
.755^{* *}\end{array}$ & 1 & & & \\
\hline $\begin{array}{l}\text { CT Supported } \\
\text { Household }\end{array}$ & $\begin{array}{l}\text { Sig. }(2- \\
\text { tailed })\end{array}$ & 0.000 & & & & \\
\hline Income & $\begin{array}{l}\mathrm{N} \\
\text { Pearson } \\
\text { Correlation }\end{array}$ & $\begin{array}{c}93 \\
.679 * *\end{array}$ & $\begin{array}{c}93 \\
.622 * *\end{array}$ & 1 & & \\
\hline $\begin{array}{l}\text { CT Supported } \\
\text { Healthcare }\end{array}$ & $\begin{array}{l}\text { Sig. (2- } \\
\text { tailed) }\end{array}$ & 0.000 & 0.000 & & & \\
\hline Access & $\begin{array}{l}\mathrm{N} \\
\text { Pearson }\end{array}$ & 93 & 93 & 93 & & \\
\hline $\begin{array}{l}\text { CT Supported } \\
\text { Investment in } \\
\text { Productive }\end{array}$ & $\begin{array}{l}\text { Correlation } \\
\text { Sig. (2- } \\
\text { tailed) }\end{array}$ & $\begin{array}{l}.726^{* *} \\
0.000\end{array}$ & $\begin{array}{l}.463 * * \\
0.000\end{array}$ & $\begin{array}{l}.534 * * \\
0.000\end{array}$ & 1 & \\
\hline activities & $\begin{array}{l}\mathrm{N} \\
\text { Pearson }\end{array}$ & 93 & 93 & 93 & 93 & \\
\hline & $\begin{array}{l}\text { Correlation } \\
\text { Sig. (2- } \\
\text { tailed) }\end{array}$ & $.699 * *$ & $.613 * *$ & $.459 * *$ & $.513 * *$ & 1 \\
\hline Empowerment & $\mathrm{N}$ & 93 & 93 & 93 & 93 & 93 \\
\hline
\end{tabular}


study findings presented in Table 3 show that cash transfer supported household income had a positive and significant effect on the economic wellbeing of persons with severe disability in Wajir County, $\beta=0.340, t=4.944, p=0.000$. The results implied that a unit increase in cash transfer supported household income would lead to increased economic wellbeing among persons with severe disability in Wajir County by 0.340 units. These findings were in line with that of Mwanzia (2015) who found that the incomes from the cash transfer program increased the purchasing power of beneficiaries enabling them to meet their basic needs and those of their households hence enabling them not having to depend on others on a daily basis. The findings are also in support of that Haushofer and Shapiro (2016) who found that incomes from cash transfers increased household expenditures and consumption of food, medicine and education expenditures.

Table 4: Regression Coefficients

\begin{tabular}{|c|c|c|c|c|c|c|}
\hline \multirow[t]{2}{*}{ Model } & & \multicolumn{2}{|c|}{$\begin{array}{c}\text { Unstandardized } \\
\text { Coefficients }\end{array}$} & $\begin{array}{c}\text { Standardized } \\
\text { Coefficients } \\
\end{array}$ & \multirow[t]{2}{*}{$\mathbf{t}$} & \multirow[t]{2}{*}{ Sig. } \\
\hline & & B & $\begin{array}{c}\text { Std. } \\
\text { Error }\end{array}$ & Beta & & \\
\hline \multirow[t]{10}{*}{1} & (Constant) & -0.173 & 0.21 & & -0.824 & 0.412 \\
\hline & Cash Transfer Supported & & & & & \\
\hline & Household Income & 0.340 & 0.069 & 0.346 & 4.944 & 0.000 \\
\hline & Cash Transfer Supported & & & & & \\
\hline & Healthcare Access & 0.157 & 0.062 & 0.167 & 2.536 & 0.013 \\
\hline & Cash Transfer Supported & & & & & \\
\hline & Investment in Productive & & & & & \\
\hline & Activities & 0.376 & 0.064 & 0.361 & 5.889 & 0.000 \\
\hline & Cash Transfer Supported & & & & & \\
\hline & Empowerment & 0.215 & 0.062 & 0.225 & 3.476 & 0.001 \\
\hline $\begin{array}{l}\text { a Depen } \\
\text { County }\end{array}$ & dent Variable: Economic & eing of & rsons и & Severe Disal & ty in $W$ & \\
\hline
\end{tabular}

The study also found that cash transfer supported healthcare access had a positive and significant effect on the economic wellbeing of persons with severe disability in Wajir County, $\beta=0.157, \mathrm{t}=2.536, \mathrm{p}=0.013$. The implication of these results was that a unit increase in cash transfer supported healthcare access would lead to an increase in the economic wellbeing of persons with severe disability in Wajir County by 0.157 units. The findings were in support of the study by Bernabe-Ortiz et al. (2016) which showed that social protection programmes enabled the disabled to access better healthcare which helped reduce their health problems and in so doing, enhancing their livelihood opportunities. The findings further agree with that of Owusu-Addo (2014) who found that cash transfer programmes reduced the financial barrier to health care as most beneficiaries were registered under the National Health Insurance Schemes and therefore enabled them to pay off and reduce healthcare related debts besides addressing the root causes of unemployment and poverty such as failure to be enrolled in school for children whose disabled parents were ill and unable to access healthcare.

It was further established that cash transfer supported investment in productive activities positively and significantly affected the economic wellbeing of persons with severe disability in Wajir County, $\beta=0.376, \mathrm{t}=5.889, \mathrm{p}=0.000$. The results implied that a unit increase in cash transfer supported investment in productive activities would lead to an increase in the economic wellbeing of persons with severe disability in Wajir County by 0.376 units. The findings supported that of Aluoch (2013) who found that with cash transfers, beneficiaries were able to set up small investments which resulted to high income which consequently led 
to better standards of living. The findings also support that of Zezza and Davis (2010) who found that by use of cash transfers, beneficiary households were able to purchase durable goods and to invest in more such as animals and land which improved their economic wellbeing which was noticeable as dependency was reduced and there was a high income rate. It was also found that the economic wellbeing of persons with severe disability in Wajir County was positively and significantly affected by cash transfer supported empowerment, $\beta$ $=0.215, \mathrm{t}=3.476, \mathrm{p}=0.001$. A unit increase in cash transfer supported empowerment would lead to increased economic wellbeing of persons with severe disability in Wajir County by 0.215 units. The findings were in line with Pavanello, Pozarny, and Ana (2015) who found that social protection programs promoted economic advancement of beneficiaries by increasing their productive resources such as income, access to credit and savings. The findings also supported the fact such programs improved the skills and employment opportunities of beneficiaries ensuring their equal access to benefits and ability to build links with community-based services and livelihood interventions.

\section{CONCLUSIONS}

Based on the study findings, the study concluded that cash transfer programme was crucial in improving the economic wellbeing of persons living with disabilities in Wajir County The study concluded that even though significant achievements had been attained under this programme, there was still room for improvement in regards to supporting the beneficiary households. The study concluded that most of the beneficiary households were yet to be reliant on other income sources other than cash transfers and that the monthly stipends given were still inadequate. The study further concluded that cash transfer supported household income, healthcare access, investment in productive activities and empowerment were fundamental aspects of the cash transfer programme that greatly affected economic wellbeing of beneficiary households. Hence, if the cash transfer programme was to achieve its objectives, the aforementioned aspects needed to be adequately embedded in the programme's outline.

\section{RECOMMENDATIONS}

Based on the study findings, a number of recommendations were made. The study recommends that the Ministry of Labour, Social Security and Services Programmes should consider increasing the monthly disbursements given to persons living with disabilities so that they can venture in to activities that would give them supplementary incomes. There can be other activities within the programme meant to support the beneficiaries to be self-reliant so that they do not have to rely on the transfers throughout. The study recommends besides ensuring that beneficiary households are registered with the National Hospital Insurance Fund, the programme overseers should push for policy guidelines which will enable beneficiaries under the programme to get access to healthcare without being subjected to major payments so as to increase healthcare utilization among the beneficiaries. The fund can partner with specific hospitals where these beneficiaries can get treatment at a very cost or where part of the medical costs are catered under the programme. The study also recommends that the officials overseeing the cash transfer programme for persons living with disabilities should have follow up programs especially for beneficiaries who have ventured in to productive activities so that they can support them to expand their income generation activities. The programme can partner with other development partners such as donors and NGOs and also the county government to create a fund where beneficiaries can get more assistance both financial and non-financial in order to expand their activities. The study recommends that the funds provided should be added in order to increase the coverage of beneficiaries who venture in to productive activities. The programme overseers can partner 
with several organizations so that persons with disability can get assistive devices so that they can be able to do daily businesses. The study further recommends that there should be increased education and awareness campaigns meant to educate the beneficiary households on the various empowerment programmes provided by established organizations such as NGOs, banks, development partners and also cooperatives within the county where they can be empowered economically and their interests championed. The beneficiaries should also be enlightened on the need for being members of self-help groups especially those which are business oriented in order to participate in group projects. The study recommends that the programme should provide networking programs were beneficiary households can interact with various organizations so as to secure livelihood opportunities such as employment.

\section{REFERENCES}

Abdulla, A. I. S. (2015). Cash transfer programming in the ASALs of Kenya: A case study to document the actions being taken to build the knowledge, attitude, practices and capacity of the county governments/state actors Retrieved from: http://www.cashlearning.org/downloads/cash-transfer-programming-in-the-asals-ofkenya.pdf

Adato, M., \& Bassett, L. (2008). What is the potential of cash transfers to strengthen families affected by HIV and AIDS? A review of the evidence on impacts and key policy debates. Washington, DC: IFPRI.

Agboga, S. R. (2015). The contributions of the districts disability common fund to the wellbeing of beneficiaries in Ada East District (Doctoral dissertation, University of Ghana).

Aluoch, O. W. (2013). Influence of cash transfer programmes on socio-economic wellbeing of beneficiary households in Bungoma County, Kenya. (Unpublished Dissertation, University of Nairobi, Nairobi).

Andrews, C., Das, M., Elder, J., Ovadiya, M., \& Zampaglione, G. (2012). Social protection in low income countries and fragile situations: Challenges and future directions. Retrieved from: https://www.google.com/url?sa=t\&rct=j\&q=\&esrc=s\&source=web\&cd=1\&cad=rja\& uact $=8 \&$ ved $=0$ ahUKEwjopC72pPYAhWEVhQKHWqTCZoQFggnMAA\&url=http\%3A\%2F\%2Fsiteresources .worldbank.org\%2FSOCIALPROTECTION\%2FResources\%2FSP-Discussionpapers\%2F4305781331508552354\%2F1209.pdf\&usg=AOvVaw0fEPC2e7rkra8Da695Hnrv

Asfaw, S., Daidone, S., Davis, B., Dewbre, J., Romeo, A., Djebbari, H., ... \& Covarrubias, K. (2012). Analytical framework for evaluating the productive impact of cash transfer programmes on household behaviour. Methodological guidelines for the Protection to Production Project.

Ayuku, D., Embleton, L., Koech, J., Atwoli, L., Hu, L., Ayaya, S., ... \& Braitstein, P. (2014). The government of Kenya cash transfer for orphaned and vulnerable children: crosssectional comparison of household and individual characteristics of those with and without. BMC international health and human rights, 14(1), 25.

Banerji, A., \& Gentilini, U. (2013, September). Social safety nets: Lessons from global evidence and practice. In Paper prepared as part of the World Bank's participation at the Bank of Namibia's Annual Symposium on Social Safety Nets in Namibia: 
Assessing Current Programs and Future Options (26 September 2013, Windhoek). Washington, DC, World Bank.

Barrientos, A., \& Lloyd-Sherlock, P. (2002). Non-contributory pensions and social protection. Issues in Social Protection.

Bernabe-Ortiz, A., Diez-Canseco, F., Vasquez, A., Kuper, H., Walsham, M., \& Blanchet, K. (2016). Inclusion of persons with disabilities in systems of social protection: a population-based survey and case-control study in Peru. BMJ Open, 6, 1-9.

Braithwaite, J., \& Mont, D. (2009). Disability and poverty: A survey of World Bank poverty assessments and implications. ALTER-European Journal of Disability Research/Revue Européenne de Recherche sur le Handicap, 3(3), 219-232.

Bryant, J. H. (2009). Kenya's cash transfer program: Protecting the health and human rights of orphans and vulnerable children. health and human rights, 65-76.

Buddelmeyer, H., \& Verick, S. (2008). Understanding the drivers of poverty dynamics in Australian households. Economic Record, 84(266), 310-321.

Chambers, R., \& Conway, G. (1992). Sustainable rural livelihoods: practical concepts for the 21 st century. Institute of Development Studies (UK).

Chambers, R., \& Conway, G. R. (1991). Sustainable rural livelihoods: practical concepts for the 21st century. Institute of Development Studies, 296.

Coleman, J. S. (1988). Social capital in the creation of human capital. American journal of sociology, 94, S95-S120.

Cooper, D. R., \& Schindler, P. S. (2006). Marketing research (p. 261). New York: McGrawHill/Irwin.

Cooper, P. R. \& Schindler, P.S. (2008). Business research methods. (10 ${ }^{\text {th }}$ ed.). Wiley, New York.

Cullinan, J., Gannon, B., \& Lyons, S. (2011). Estimating the extra cost of living for people with disabilities. Health Economics, 20(5), 582-599.

Daniels, L. (1999). The role of small enterprises in the household and national economy in Kenya: A significant contribution or a last resort? World Development, 27(1), 55-65.

Davis, B., \& Pozarny, P. (2012). Qualitative research and analyses of the economic impacts of cash transfer programmes in sub-Saharan Africa (No. 184).

Department for International Development, (DFID). (2011). Cash transfers: Evidence paper policy division. Retrieved from: http://www.who.int/alliancehpsr/alliancehpsr_dfidevidencepaper.pdf

Devereux, S. (2001). Livelihood insecurity and social protection: a re- emerging issue in rural development. Development policy review, 19(4), 507-519.

Devereux, S., \& Sabates-Wheeler, R. (2004). Transformative social protection. Institute of Development Studies (IDS) Working Paper 232.

Eide, A. H., \& Kamaleri, Y. (2009). Living conditions among people with disabilities in Mozambique: A national representative study. Oslo, SINTEF.

Eide, A. H., \& Loeb, M. E. (2005). Data and statistics on disability in developing countries. Disability Knowledge and Research Programme Executive Summary. 
FAO (2014). Qualitative research and analyses of the economic impacts of cash transfer programmes in sub-Saharan Africa: Kenya Country Case Study Report. Food and Agriculture Organization of the United Nations: Rome, Italy.

Giovannetti, G. (2010). Social Protection for Inclusive Development. A New Perspective in EU Cooperation with Africa. Retrieved from: http://cadmus.eui.eu/handle/1814/15496

Hailu, D. \& Veras Soares, F. 2008. Cash Transfers in Africa International Poverty Centre and Latin America: An Overview. In: Hailu, D. and F. Veras Soares, eds. Cash Transfers Lessons from Africa and Latin America. Poverty in Focus Number 15, August 2008. International Poverty Centre

Handa, S. (2012). Kenya Cash Transfer for Orphans and Vulnerable Children Evaluation: Sample Design and Description. UNICEF, UNC, and FAO. Available at:< http://www. fao. org/fileadmin/user_upload/p2p/Publications/Kenya_CT-OVC_ Sample_Design_and_Description_2012.pdf>(accessed 8 November 2015).

Handina, J., Ncube, A., Jordaan, A., \& Ncube, M. A. (2008). An analysis of the efficacy of cash transfers in addressing food insecurity for Mutare urban communities of Zimbabwe.

Retrieved

from: http://s3.amazonaws.com/academia.edu.documents/34673891/Alice_James_paper.p df?AWSAccessKeyId=AKIAIWOWYYGZ2Y53UL3A\&Expires=1497858924\&Sign ature $=3 Z$ HerwDZ11OWvswZU2ZqIATuvbg\%3D\&response-contentdisposition=inline\%3B\%20filename\%3DAn_analysis_of_the_efficacy_of_cash_tran. pdf

Haushofer, J., \& Shapiro, J. (2016). The short-term impact of unconditional cash transfers to the poor: Experimental Evidence from Kenya. The Quarterly Journal of Economics, 131(4), 1973-2042.

Hawking, S. (2014). Disability and vulnerability. United Nations Development Programme Human Development Reports. Retrieved from: http://hdr.undp.org/en/content/disability-and-vulnerability

Houtenville, A. J. (2009). Counting working-age people with disabilities: what current data tell us and options for improvement. WE Upjohn Institute.

Kenya Inter Agency Rapid Assessment (KIRA). (2014). Wajir County Conflict Assessment Report.

Retrieved

from https://www.humanitarianresponse.info/sites/www.humanitarianresponse.info/files/as sessments/Kenya\%20Interagency\%20Rapid\%20Assessment_Wajir\%20County_Augu st\%202014.pdf

Kimosop, E. J. (2013). Cash transfer and its impact on the welfare of the elderly in Kenya: A case of the Government of Kenya's Older Persons Cash Transfer Programme in Makueni County (Doctoral dissertation).

Krantz, L. (2011). The sustainable livelihood approach to poverty reduction. SIDA. Division for Policy and Socio-Economic Analysis.

Lerisse, F., Mmari, D., \& Baruani, M. (2013). Vulnerability and Social Protection Programmes in Tanzania. A study on Social Protection Programmes on Vulnerability For the Research and Analysis Working Group.

Loeb, M., Eide, A. H., Jelsma, J., Toni, M. K., \& Maart, S. (2008). Poverty and disability in eastern and western cape provinces, South Africa. Disability \& Society, 23(4), 311321. 
Majale, M. (2012, May). Towards pro-poor regulatory guidelines for urban upgrading. In $A$ review of papers presented at the International Workshop on Regulatory Guidelines for Urban Upgrading held at Bourton-on-Dunsmore.

McGillivray, M. (2007). Human well-being: Issues, concepts and measures. In Human WellBeing (pp. 1-22). Palgrave Macmillan UK.

Miako, G. N., \& Wanjohi, J. M. (2017). Factors influencing civil registration of household in cash transfer for orphans and vulnerable children programme in Karaba location, Mbeere South Sub-county. International Academic Journal of Information Sciences and Project Management, 2(2), 87-99.

Ministry of State for Planning, National Development and Vision 2030. (2012). Kenya Social Protection Sector Review, Nairobi based on KIHBS 2005/06 and the 2009 Census

Mitra, S. (2010). Disability cash transfers in the context of poverty and unemployment: The case of South Africa. World Development, 38(12), 1692-1709.

Mitra, S., Findley, P. A., \& Sambamoorthi, U. (2009). Health care expenditures of living with a disability: total expenditures, out-of-pocket expenses, and burden, 1996 to 2004. Archives of physical medicine and rehabilitation, 90(9), 1532-1540.

Mogaka, M. M., \& Student, D. B. (2013). The effects of cash transfer programmes on Orphans and Vulnerable Children's (OVCs) wellbeing and social relations: A case study of Nyamira Division, Nyamira County (Doctoral dissertation, University of Nairobi).

Morse, S., \& McNamara, N. (2013). The Theory Behind the Sustainable Livelihood Approach. In Sustainable Livelihood Approach (pp. 15-60). Springer Netherlands.

Mutambara, C. R. (2014). An evaluation of cash transfer programmes in Zimbabwe as a strategy to reduce poverty: a case study of Mercy Corp's cash transfers programme in Sakubva high density suburb, Mutare. (Unpublished Dissertation, University of Zimbabwe, Zimbabwe).

Mutiga, N. G., \& Wanyoike, D. M. (2016). Assessment of effectiveness of cash transfer program on people with severe disabilities in Rongai Sub-county. International Journal of Economics, Commerce and Management, 4(5), 591-616.

Mwanzia, P. M. (2015). The effect of older persons' cash transfer programme on the elderly in Westlands Sub-county, Nairobi City County. (Unpublished Dissertation, University of Nairobi, Nairobi).

National Gender and Equality Commission, (NGEC). (2014). Participation of vulnerable populations in their own programmes: The cash transfers in Kenya. Retrieved from: http://www.ngeckenya.org/Downloads/cash-transfer-programme-vulnerable-groupskenya.pdf

Nkpoyen, F., Mbat, M. D., Eteng, B. G. (2015). Empowerment programmes and socio economic wellbeing of rural women: A study of "First Ladies" Projects in Akwa Ibom State, Nigeria. Journal of Humanities and Social Science, 20(7), 35-44.

Norton, A., \& Foster, M. (2011). The potential of using sustainable livelihoods approaches in poverty reduction strategy papers. London: Overseas Development Institute.

O'Keefe, P. (200). People with disabilities in India: From commitments to outcomes. Human Development Unit, South East Asia Region, The World Bank, 157. 
Oddsdottir, F. (2014). Social protection programmes for people with disabilities. Retrieved from: http://www.gsdrc.org/docs/open/hdq1137.pdf

Onyango-Ouma, W., \& Samuels, F. (2012). Transforming cash transfers: Beneficiary and community perspectives on the cash transfer for orphans and vulnerable children programme in Kenya. London, UK, and Nairobi, Kenya.

Orando, M. (2013). The influence of human behaviour factors on construction productivity (Doctoral dissertation, University of the Free State).

Owen, R. J. (2011). Disability Rights, Employment and Welfare: People with Disabilities in Liberal Welfare States (Doctoral dissertation, University of Leeds (United Kingdom).

Owusu-Addo, E. (2014). Perceived impact of Ghana's conditional cash transfer on child health. Health Promotion International, 31(1), 33-43.

Parodi, G., \& Sciulli, D. (2008). Disability in Italian households: income, poverty and labour market participation. Applied Economics, 40(20), 2615-2630.

Pavanello, S., Pozarny, P., \& Ana, P. (2015). Qualitative research on women's economic empowerment and social protection. Food and Agriculture Organization of the United Nations (FAO), Rome, Italy.

Ressler, P. (2008). The social impact of cash transfers: A study of the impact of cash transfers on social networks of Kenyan households participating in cash transfer programs. International Food Policy Research Institute.

Sabates-Wheeler, R., \& Waite, M. (2003). Migration and Social Protection: A concept paper. Institute of Development Studies, Sussex, December, 1645, 1980-2000.

Saunders, P. G. (2006). The costs of disability and the incidence of poverty. Social Policy Research Centre.

Schwarze, J. (2008). Subjective measures of economic well-being and the influence of income uncertainty. Retrieved from: Schwarze, J. (2008). Subjective measures of economic well-being and the influence of income uncertainty.

She, P., \& Livermore, G. A. (2009). Long-term poverty and disability among working-age adults. Journal of Disability Policy Studies, 19(4), 244-256.

Stefanoni, S., Williamson, C., Bukuluki, P., Wandiembe, S. P., Van Eys, T., \& LloydSherlock, P. (2017). Cash transfers and older people's access to healthcare: A multicountry study in Ethiopia, Mozambique, Tanzania and Zimbabwe. HelpAge International: London, United Kingdom

Tiliouine, H. (2007). Health and Subjective Wellbeing in developing countries: The case of Algeria. WeD Working Paper 39, ESRC Research Group on Wellbeing in Developing Countries. UK: University of Bath. Retrieved from http://www. welldev. org. uk/research/workingpaperpdf/wed39. pdf.

Trani, J., Bah, O., Bailey, N., Browne, J., Groce, N., \& Kett, M. (2010). Disability in and around urban areas of Sierra Leone. London, Leonard Cheshire International.

Vincent, K., \& Cull, T. (2009). Impacts of social cash transfers: case study evidence from across southern Africa. Instituto de Estudos Sociais e Económicos.

Wajir County Government and World Food Programme, (WFP). (2015). Wajir County: Capacity gaps and needs assessment for food security safety nets and emergency preparedness and response. World Food Programme. 
Wanjohi, C. W. (2014). The role and sustainability of cash transfer programmes in poverty reduction on female-headed households in Mukuru slums of Nairobi City County (Doctoral dissertation, University of Nairobi).

World Bank 2013. Kenya Cash Transfer for Orphans and Vulnerable Children (CT-OVC) Project. Available at: http://go.worldbank.org/OGO001TD50. [Accessed 30 May 2017].World Bank 2014).The State of Social Safety Nets 2014. World Bank, Washington DC.

World Health Organization. (2004). The impact of health expenditure on households and options for alternative financing. http://www.who.int/health_financing/documents/emrc51-4healthexpenditureimpact.pdf?ua $=1$

Zaidi, A., \& Burchardt, T. (2005). Comparing incomes when needs differ: Equivalization for the extra costs of disability in the UK. Review of Income and Wealth, 51(1), 89-114.

This is an open-access article published and distributed under the terms and conditions of the $(\mathrm{cc}) \mathrm{EY}$ Creative Commons Attribution 4.0 International License of United States unless otherwise stated. Access, citation and distribution of this article is allowed with full recognition of the authors and the source.

Authors seeking to publish with an International Peer Reviewed Journal should consider www.ijcab.org by writing to the Editor at editor@ijcab.org. 